СТРУЧНИ ЧЛАНЦИ

ПРОФЕССИОНАЛЬНЫЕ СТАТЬИ

PROFESSIONAL PAPERS

\title{
IMPROVED TECHNICAL \\ CHARACTERISTICS OF THE MI-8/17 IN THE ARMY OF FYR MACEDONIA
}

Drage T. Petreski ${ }^{a}$, Andrej P. Iliev ${ }^{b}$, Elena M. Trajanovska ${ }^{c}$, Lazar B. Gjurov ${ }^{\mathrm{d}}$, Aleksandar S. Petrovski ${ }^{\mathrm{e}}$

Military Academy „General Mihailo Apostolski“, Skopje, FYR Macedonia

a e-mail: drage_petreski@yahoo.com,

ORCID iD: (Dhttp://orcid.org/0000-0002-5830-1389

be-mail: andrej220578@gmail.com,

ORCID iD: :http://orcid.org/0000-0002-7917-1966

${ }^{c}$ e-mail: ebatkoska@gmail.com,

ORCID iD: (Ohttp://orcid.org/0000-0003-4558-1382

de-mail: lazar.gjurov@gmail.com

ORCID iD: http://orcid.org/0000-0002-7608-2802

e e-mail: aleksopetrovski@gmail.com

ORCID iD: -

http://dx.doi.org/10.5937/vojtehg66-14520

FIELD: aerospace engineering, electronics, telecommunications

ARTICLE TYPE: Professional Paper

ARTICLE LANGUAGE: English

Abstract:

Worldwide experience has shown that MI-8/17 helicopters are on the top of the middle class list of high performance multipurpose helicopters, flying at high altitudes in complex meteorological conditions.

The paper addresses their development, transport, as well as rescuing and combat capabilities. The excellent technical characteristics of flight and their capabilities for uninterrupted and smooth performance of tasks demonstrate the reason why the Armed forces of the FYR of Macedonia decided to use Mi-8/17 helicopters and are determined to invest in their modernization and improvement of their technical capabilities. The modernization of the resources of armies is a continuous process, which is a part of all modern military security structures. Most armed forces do not economize the funds allocated for this purpose, due to the fact that 
they aspire to achieve the planned capabilities, so that they would attain the ultimate preparedness in terms of capabilities of the security forces regarding technology and trained personnel.

Key words: modernization, technical capabilities, project, aircraft, performance, force.

\section{Introduction}

Helicopters are among the first aircraft designed by people; however, it took a long time before they were put in use. Bringing the idea to fruition was not so easy. The first records of the concept of helicopters as aircraft date back from the end of the 15th century, the period of Leonardo da Vinci, one of the greatest minds of the renaissance. Since then, the improvement of helicopter technology has not stopped its development. One of many scientists who have contributed to its development is the renowned Russian scientist and helicopter designer Mikhail Mil, 1900-1970.

This scientist became famous for his merits of Mi-8/17 helicopters design, one of many famous twin engine helicopters in the world, included in the list of the most popular aircraft of its type in the world history of aviation.

On August 2 1962, the first prototype of the multipurpose Mi-8/17 helicopters had its first flight (www.topwar.ru). It is currently the most popular twin turbine multipurpose helicopter in the world and the most mass produced helicopter in the history of aviation, used for numerous civilian and military tasks.

The Mi-8 program was followed by a tremendous technical documentation, modification, and improvement: 12000 copies in different variants were produced. Based on the experience and the results of the $\mathrm{Mi}-8$, this famous helicopter, which is capable of landing on a water surface, was developed under the designation Mi-14 (http://kollektsiya.ru).

Aviation, as one of the most complex components of the Republic of Macedonia's defence system, requires a special focus on the area of modernization of the Mi-8/17, as the most typical and most used aviation technique in the Macedonian Air Force. The transport component is essential for the airlift and multipurpose capabilities of the Armed Forces aircraft. Equipping the helicopters is only one part of the problem that has emerged in the recent years besides the outdating of the aircraft (Dicevski, 2012, pp.21-22). 


\section{Technological development}

Although most of the historians mainly focus on aircraft with fixed wings, a helicopter flight was the first flight conceptualized by people. As a matter of fact, ancient Chinese played with mobile tops which flew by accelerated rotation of their wings. These tops occurred approximately in 400 B.C. in China and were the subject of experimentation by Sir George Cayley, the father of modern aeronautics. These tops occurred in Europe in the period of renaissance on the Leonardo da Vinci's drawings and sketches (Božić, 2010).

In 1483, Leonardo da Vinci made a sketch of a helicopter with a rotor in the form of a big spiral made of canvas. He named the device helixpteron, coined of two Greek words: helix which means a spiral and pteron which means a wing or "spiral wing" (Kuzmanovski, 2003). The idea has been recognized as the first solution for an aircraft, which would be developed half a millennium later and would be called a helicopter (Donald, 1977, p.403).

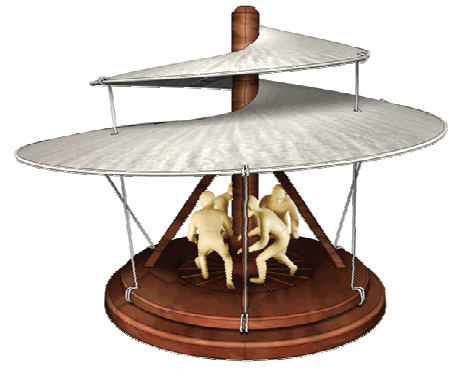

Figure 1 - Helixpteron - Leonardo da Vinci's helicopter

Рис. 1 - «Хеликсптерон» - винтокрыл Леонардо да Винчи

Слика 1 - Хеликсптерон - хеликоптер Леонарда да Винчија

2,000 years upon the occurrence of the Chinese flying tops, in July 1754, the Russian scientist Mikhail Lomonosov used them to develop a small coaxial rotor, powered by a wound-up spring (Leishman, 2006, p.8). In 1783, the French naturalist Launoy, helped by a mechanic named Bienvenue, constructed a device with counter-rotating pair of rotors made of turkey feathers based on the coaxial Chinese tops. It was a relatively large device, the movement of which was helped by a fish line wound around the rotor's axis and wound up on a crossbow (Museo nazionale scienza e tecnologia Leonardo Da Vinci, 1999).

The aforementioned Sir George Cayley, as a young boy, was fascinated by the Chinese top and by the end of the 18th century 
constructed several successful vertical-flight models with rotors made of sheets of tin, driven by wound-up clock springs. His fascination with flying at a very early age, in 1804, inspired him to design and construct rotating blades, which is probably one of the first scientific research works on the aerodynamic forces of aircraft wings. In the paper published in 1843, Cayley provides details on a relatively large aircraft for vertical flight, which he named "aerial carriage" (Gordon, 2007).

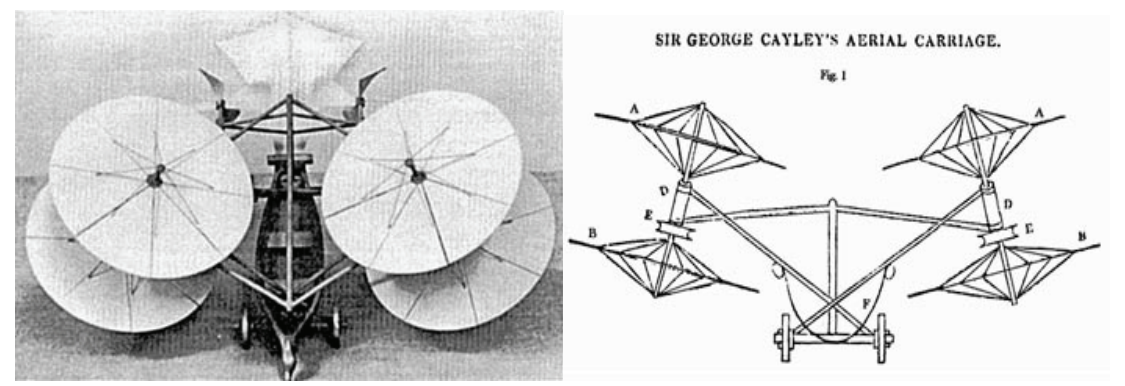

Figure 2 - Aerial carriage, 1843

Puc. 2 - Воздушная карета, 1843 г.

Слика 2 - Ваздушна кочија из 1843. године

The absence of an appropriate propulsion machine slowed down the development of aircraft heavier than air, regardless of whether they had fixed or rotating wings. However, the use of miniature, light steam engines yielded some success. In 1861, the French inventor Gustave de Ponton d'Amécourt coined the word "helicopter" and demonstrated a model of a small flying device propelled by a steam engine (Rumerman, 2003, p.13).

This big issue was solved by the Spanish Juan de la Cierva by creating the mobility of the rotor (Bryan, 1926, p.249).

In 1923, Lieutenant Colonel Gomez Spencer of Spain flew the first successful autogiro of de la Cierva. In 1925, he brought his „C.6“ to Great Britain and demonstrated it to the Air Ministry at Farnborough, Hampshire (Pioneers-1900/1930, Helicopter History Site).

In 1906, two French brothers Jacques and Louis Breguet, began experimenting with airfoils for helicopters. In 1907, those experiments resulted in the first gyroplane, possibly as the earliest known example of a quadcopter (Božić, 2010, p.6). Although there is some uncertainty about the date, sometime between August 14 and September 29, 1907, the Gyroplane No. 1 lifted into the air about 0.6 meters for a minute (Kenneth, 1968 , p.176). The Gyroplane proved to be very unsteady, and it is considered to be the first flight of a helicopter, but not a free and untethered flight. That same year, the French inventor Paul Cornu designed and built a helicopter called "Cornu helicopter" that used $6 \mathrm{~m}$ 
counter-rotating rotors driven by a $24 \mathrm{hp}, 18 \mathrm{~kW}$ Antoinette engine, the first internal combustion engine, most aircraft from the past were equipped with. On November 13, 1907, he managed to lift its invention to $0.3 \mathrm{~m}$ off the ground and remained aloft for 20 seconds. Even though this flight did not surpass the flight of the Gyroplane No.1, it is considered to be the first free flight with a pilot (Leishman, 2006, p.17). Étienne Oehmichen was a French helicopter engineer and designer. The first successful flight of his helicopter, called Oehmichen No.2, was completed in 1922. That was the first safe flying device capable of carrying one person.

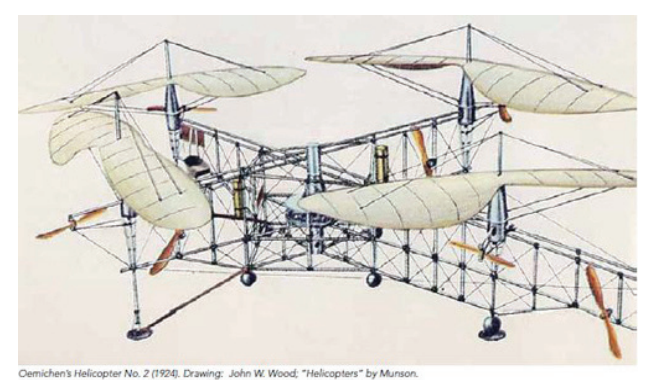

Figure 3 - Helicopter Oemichen No.2 from 1924

Puс. 3 - Вертолет Оихмичена №2, 1924 2.

Слика 3 - Хеликоптер Oemichen број 2 из 1924. године

The project of Louis Breguet from France was of great importance; he constructed a helicopter with a coaxial counter-rotating rotor. In 1933 he founded the company Syndicat d'Etudes du Gyroplane (Božić, 2010, p.14). In 1936, Breguet's Gyroplane set a record in four categories: height of flight of $158 \mathrm{~m}$, duration of flight of $1 \mathrm{~h} 2 \mathrm{~min} .5 \mathrm{sec}$., horizontal flight of $44 \mathrm{~km}$ and a maximum speed of $44,692 \mathrm{~km} / \mathrm{h}$. Nowadays, Breguet's Gyroplane is considered to be the first practical helicopter (Božić, 2010, p.15).

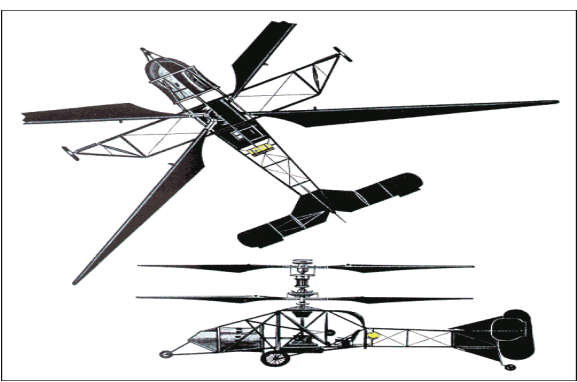

Figure 4 - Breguet's Gyroplane (1933)

Pис. 4 - Гироплан Бреге (1933 2.)

Слика 4 - Жироплан Breguet (1933) 
At the same time, the German aviation engineer Heinrich Karla Johanna Fockea presented his model Fw.61, which soon proved to be superior in comparison to Breguet's Gyroplane. From 1937-1939, Fw.61 set new records in all categories as the most successful helicopter, which were not toppled for a long time. Some of them are the following: maximum height of $3427 \mathrm{~m}$, vertical flight of $230.348 \mathrm{~km}$ and maximum speed of $112 \mathrm{~km} / \mathrm{h}$ (Focke-Wulf Fw 61/Fa 61 Experimental Helicopter/Technology Demonstrator, 2015).

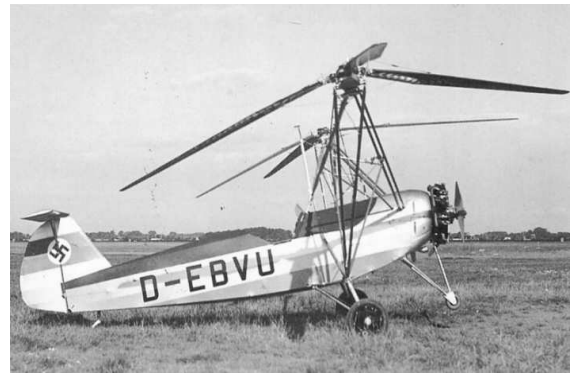

Figure 5 - The first flight of the Focke-Wulf Fw 61 (June 26, 1936)

Puc. 5 - Первый полет Focke-Wulf Fw 61 (26 июня 1936 г.)

Слика 5 - Први лет летелице Focke-Wulf Fw 61 (26. јун 1936. године)

Igor Sikorsky constructed his first helicopter in 1909 in Russia. Unfortunately, this model could not take off. His next model flew, but it did not have enough force to carry the pilot. After the revolution in 1917, Sikorsky immigrated to America, where he continued his work on helicopters. In 1939, he finally managed to build his first practical helicopter - model VS-300 (Sikorsky, 2013).

On May 6, 1941, it toppled the record held by Fw.61 with a flight of $1 \mathrm{~h}$ $32 \mathrm{~min} .26 .1 \mathrm{sec}$. In the following several years, Sikorsky worked extensively on his model and finally made a helicopter, which surpassed Breguet's Gyroplane and Fw.61 in all aspects (Edwin, 2010, p.117).

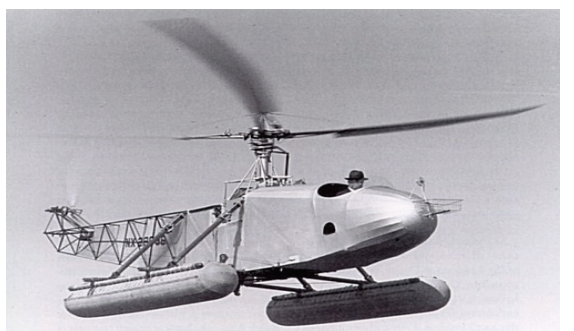

Figure 6-Igor Sikorsky in the last version of the VS-300, at the end of 1941 Puc. 6 - Окончательная версия VS - 300 Игоря Сикорскго, конец 19412. Слика 6 - Игор Сикорски с последњом верзијом VS-300, крајем 1941. године 
In 1951, Charles Kaman modified his K-225 model to enable it to the new type of engine - turbine engine (Swanborough \& Bowers, 1990, pp.432-435). This provided a drastic increase of power, whereas on December 11, 1951, the first gas-turbine-engine helicopter flew.

\section{Mi-8/17 Helicopters}

After the end of World War II, and the first successful use of the helicopters in combat, the Soviets intensified the development of this category of aircraft. One of the first steps was the forming of the Moscow Helicopter Institute in 1947, whose chief constructor was Mihail Mil and the Experimental-Construction Bureau Kamov in 1948 headed by Nikolay Kamov. The first serial-produced helicopter in the USSR was Mi-1, the first take-off took place in September 1948, whereas the first serious step forward was made upon its presentation by Stalin in 1951. The following successful step in the development of the Mil helicopters was the Mi-4 project, when the political top of the USSR insisted on rapid development of transport helicopters. The first prototype flew in June 1952. At first glance, it became clear that it is under a strong innovation influence of the American transport helicopter S-55; however, Mi-4 offered a higher performance level. (Vlačić, 2015, p.36).

The combat multirole Mi- 4 could transport around 19 paratroopers behind the enemy lines, and could transport eight stretchers, an artillery gun, or a car vehicle. The army at that time was satisfied with this type of a helicopter, but the designer estimated that it was time to introduce the turbine engine helicopter (Flot $2017 \mathrm{Mi}-8$ / Mi-17, 2011).

The twin-engine concept and the new five-bladed main rotor met the set requirements, and the first serial samples of both prototypes of the production line were launched in 1965 , one in the combat variant V-8AT and the other intended for VIP transport V-8AP. The designed helicopter which could meet these conditions was named Mi-8. In fact, it was a superior Mi-4 with a maximum carrying capacity -2.5 times greater and 1.4 times greater velocity. Mi-8's air-lift is similar to that of the Mi-4. After some modifications in 1967, it was introduced in the Soviet Air Force as the Mi-8 (Gordon \& Komissarov, 2004, p.101). 


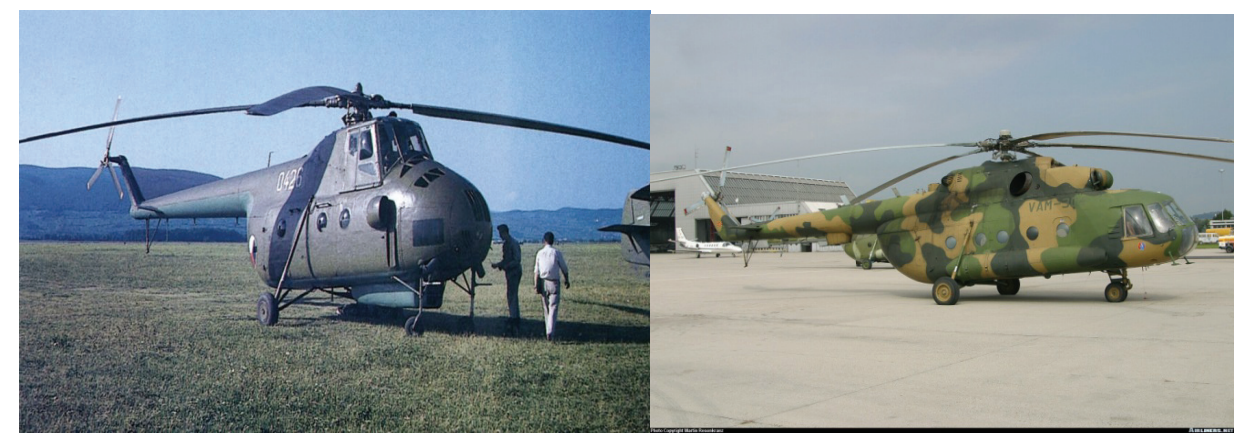

Figure $7-\mathrm{Mi}-4$ (left) and Mi-8 (right)

Puс. 7 - Мu-4 (слева) и Ми-8 (справа)

Слика 7 - Ми-4 (лево) и Ми-8 (десно)

The Mi-8 development was in full rise when the chief designer Michael Miles was sent to the US for evaluation, and if possible to buy several helicopters from the "Sikorsky" company. The main objective was to explore and examine the produced American helicopters.

After Khrushchev had been released from all his functions in the Soviet Union, in 1964, the Air Force Command did not introduce the Mi-8 helicopters into operational use. Only a few dozen samples were bought for testing. However, unlike the Army, the Ministry of Civil Aviation introduced the Mi-8 into mass use.

In June 1965, the Soviet Union was represented at the Le Bourget International exhibition, near Paris, with their Mi-8, Mi-6 and Mi-10 helicopters. Their appearance was sensational and highly rated among world experts. After this great success at Le Bourget, the military leadership began to appreciate the high quality of the Mi-8. It began to be used for mass transport, medical services, electronic warfare, air command post, and for other purposes (Yefim \& Dmitriy, 2004).

The serial production was assigned to the factory in Kazan starting from 1970 and to the factory in the Siberian town Ulan-Ude, as well. These two factories have been producing Mi-8/17 helicopters to this day (Vlačić, 2015, p.38).

Mi-8/17 helicopters are among the most successful Soviet helicopters in the history of aviation. They demonstrate high flight performance, safety, and can be used in a wide range of temperatures $\left(-50\right.$ to $\left.+50^{\circ} \mathrm{C}\right)$, flexibility, ease of exploitation and maintenance, all of which are features enabling operator gain trust in these aircraft as the best helicopters at a global level (Russian Helicopters, 2015). 


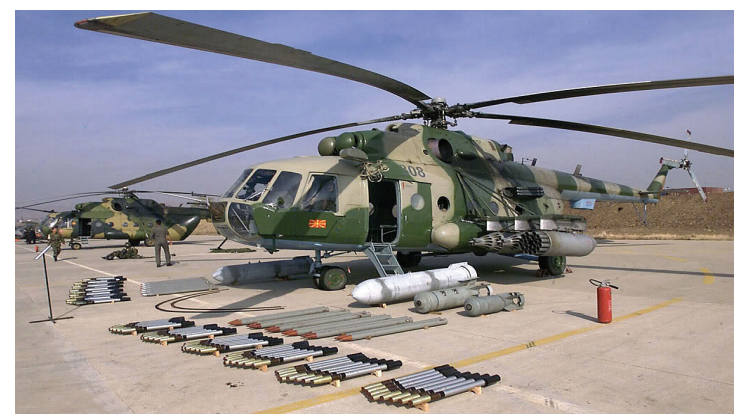

Figure 8 - Macedonian military-transport helicopter Mi-8/17

Pис. 8 - Македонский военно-транспортный вертолет Mu-8/17

Слика 8 - Македонски војни транспортни хеликоптер Мu-8/17

The Mi-8/17 remained popular due to its constant modernization, as well as due to its possibility for additional equipment for various tasks, such as the following:

- The Mi-8/17 transport version which enables transport of various types of cargo weighing up to $4000 \mathrm{~kg}$. The cargo can be placed inside the cargo cabin or attached on an external lever (Army technology Mi-8/17 Hip Multimission Helicopter, Russia, 2015).

- The version for transport of people can carry up to 26 passengers. The helicopter has an excellent system of noise and vibrations control, and is equipped with an air conditioner in the cockpit, as well as emergency exits in accordance with the regulations on safety and comfort of passengers during the flight. The Mi-8/17 VIP version is intended for transport of 7-14 passengers in a superior cockpit. The interior of the helicopter can be designed to fit the clients' desires. The helicopter is characteristic for the largest cockpit in its class and is ideal for luxurious equipment. The VIP version can be equipped with entertainment systems, satellite communication, and other equipment requested by clients.

- The search and rescue version enables efficient search and rescue missions around the clock and in all weather conditions. The helicopter is equipped with special equipment: searchlights, winches, speakers and radar systems. The search and rescue version is used by special teams of ministries and agencies for emergency situations in different countries around the world.

- Mi-8/17 version called "Flying ambulance" is designed to provide medical aid in remote and inaccessible areas. Special on-board medical provides maintenance of the vital functions of patients and first aid during the journey to hospital. Thanks to special medical materials, disinfection of the cabin can be conducted in compliance with the medical requirements. 
- The Mi-8/17 fire-fighting version provides the use of fire-fighting devices, such as a large tank that can deliver up to 4000 litters of water, and release it at the target burn area with high degree of accuracy. The helicopter can be adjusted with additional fire-fighting equipment (Helitage Mi Helicopters, 2013).

- Mi-8/17 helicopters are manufactured in the Aviation Institute "UlanUde", as well as in the central helicopter plant "Russian helicopters" in Kazan. Today, over 50 countries have Mi-8 helicopters in operational use, including India, China, Iran and other major countries. More recently, a transport Mi-17 version was developed with more powerful engines, which is today used in more than 20 countries worldwide (Helicopters Mi-8, 2015).

All these helicopters had an immense significance for the growth and industrialization of the USSR, especially in the Siberian area. Under the auspices of Aeroflot, in the period from 1975 to 1990, several hundreds of helicopters of the mentioned type were used. The most famous projects in which the helicopter had a share were: laying pipes for a nearly 2,000 km long pipeline between northwestern Siberia and the Urals, drilling and putting into operation of one of the richest oil fields in the Tyumen region in western Siberia in the length of about $4000 \mathrm{~km}$. The original initiative of Khrushchev to leave the Mi-8 project to the competence of civil structures should be regarded in this context (Vlačić, 2015, p.37). The real test in the combat use of the Mi-8 helicopters was the Soviet intervention in Afghanistan. In the early stages of the operation, they used the Mi-8T to transport the troops to inaccessible terrain. This lasted very briefly because in conditions of flight at high altitudes and at high temperatures this helicopter did not possess the sufficient power. Thus, the Mi-8MT was introduced, whereas Mi-8T was handed over to the Afghan allies. The Mi8MT helicopter proved to be the right solution for transporting troops and cargo with medium weight and size, especially to remote areas of hills and mountains. However, the inadequate protection from infantry ammunition and mobile rocket systems was the main shortfall. Thus, the next version Mi-8MTV-1 was equipped with more powerful engines TV3-117VM, 1.618 $\mathrm{kW}$. It was equipped with a new meteorological radar in its front part, as well as with new navigation equipment. The sides of the cockpit are equipped with padded plates, fuel tanks were equipped with polyurethane foam, and were incorporated in the protection system and elements for self-protection from IC-guided missiles. When it came to exported helicopters, the export mark was Mi-17, whereas the Mi-8 mark was kept for local use, for instance the aircraft marked Mi-8MTV-1 was designated Mi-17-1V when intended for export. Western civilian companies 
recognized these helicopters as reliable and inexpensive products, easily adaptable to their own needs, without major testing and financial expenditures. (Vlačić, 2015, p.40).

Taking into account the significance of this helicopter for a great number of aviations around the world, which own hundreds of helicopters of this type with a newer production date and a large list of ordered aircraft, there is definitely no dilemma regarding the prospects of the aircraft despite the approximately six-decade old design. (Vlačić, 2015, p.42).

\section{Improvement of the Mi-8/17 technical characteristics by modernization}

The development of the aviation and military technology also has enabled the emergence of efficient and modernized fighter aircraft. The contributions to the development of technology are even more evident in the field of transport helicopters because their implementation is far more universal. In the past few years, several types of modernizations of transport helicopters have appeared in the world, abilities and performances of which far exceed the current capabilities of the existing transport helicopters.

It was necessary to modernize the helicopters available to the Macedonian Armed Forces in accordance with the NATO and ICAOstandards. Analyzes were made by the expert team of the Macedonian Air Force, and it was concluded that the modernization of the helicopters is the most inexpensive option, given that the value of the project for the entire fleet of 10 helicopters is equal to the cost of only two new combat aircraft (Ministry of Defence of the Republic of Macedonia, 2012, p.79). Out of the offered companies for modernization of helicopters, the Israeli company "Elbit Systems", one of the leading companies in the world for military defence electronics and electro systems, offered the best tender conditions for the upgrade.

The process of modernization was divided into two stages: the basic stage, level 1 - "Jasmin" and the advanced phase, level 2 "Alexander", i.e. differentiation regarding the level of equipping of helicopters. The first stage included the installation of a night flying system, whereas the advanced second stage was a larger and more comprehensive project with the installation of an equipment package for navigation, communication, identification, protection of helicopters, etc. (Dicevski, 2014, p.23). After the first stage of the project, called "Jasmin", which 
began in 2004, during which two transport Mi-17 were upgraded, Macedonia joined the countries that can commend that they have aircraft with a "head-up display", digital projection of all parameters on the pilot's visor. The project included the modernization of the helicopters' collective lever, partial modification of the navigation and identification systems, the helicopters' cabin modification, and the installation of electrical and mechanical installations aiming to incorporate the latest night flight equipment known as ANVIS-HUD 24 (Army of the Republic of Macedonia, 2014).

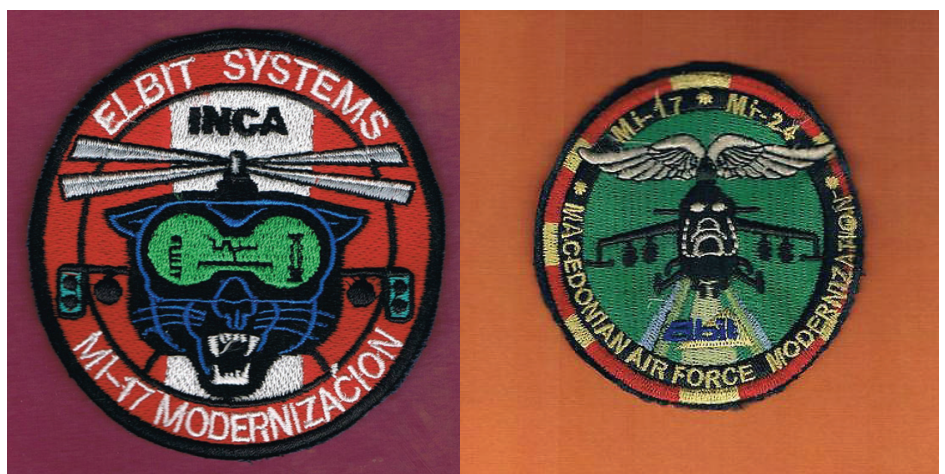

Figure 9 - Emblems of the Israeli company "Elbit Systems" during the modernization Puc. 9 - Эмблемы израильской компании "Elbit Systems" в течение модернизации

Слика 9 - Амблеми израелске компаније „Elbit Sistemi” током модернизације

The modernized helicopters and the overall results from the first stage are just the beginning of the Macedonian helicopters' modernization, which upon the finalizing of the second stage called "Alexander" by the end of 2007 , would be supplemented by six others, such as the combat Mi-24 type and the transport $\mathrm{Mi}-17$ and $\mathrm{Mi}-8$, with built-in night flight system, instrumental takeoff and landing system, radio communication equipment, digital navigation system, optic electronic systems with thermal cameras for detection, monitoring and shooting of ground targets, day and night, in all weather conditions.

The stage of system modules setup is followed by the stage of system testing for night flights ANVIS / HUD 24 on the ground, realization of the helicopter test flights in the air, as well as the completion of the necessary documentation and handing over of helicopters.

\section{"ANVIS HUD-24" System}

The installation of the "ANVIS HUD-24" System provides, first and foremost, flying and monitoring of the parameters projected on the display, 
without deepening of the sight in the cabin. It provides a 24-hour operational capability of an integrated system. The integrated system includes standard glasses for night flight, NVG - Night Vision Goggles, displaying the flight parameters of the HUD System, Head Up Display System. The system enables the pilot to keep his attention on the external conditions and at the same time flight information is presented on the display at night and during the day, integrated with NVG. It is a set of different symbols linked to specific missions selected by the pilot in order to increase the situational awareness during the operation with the helicopter, complex manoeuvres and reduced visibility at night. This configuration is currently operational in over 4500 helicopters in the world.

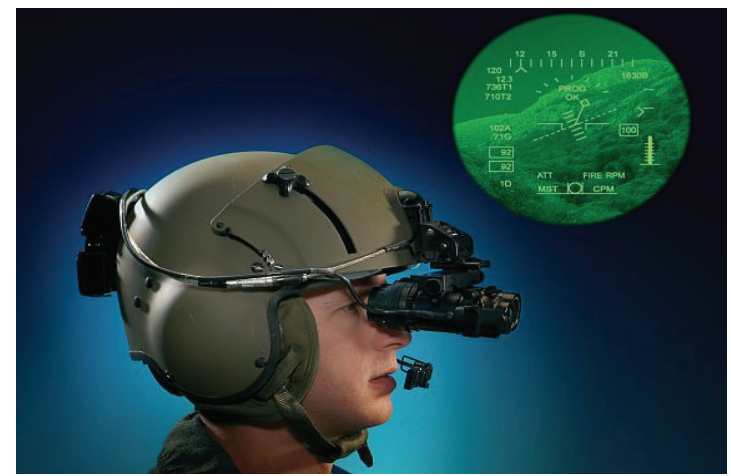

Figure 10 - ANVIS HUD with the head-up display Puc. 10 - ANVIS HUD с нашлемным целеуказателем Слика 10 - ANVIS HUD ca head-up дисплејом

HUD - systems, day and night, enable the digitalization of mechanical and analogue parameters on the electronic digital displays; they are clear, understandable and easy to follow, upon the completion of the flight crew training. The system implements advanced technologies, modern electronics, and cutting-edge optical design intended to maximize the scope of view with high reliability, brightness, wide angle view, uniformity of symbols and various configurations (Yona at al, 2004, pp.225-235 ).

\section{Mission Management System}

The MMS - Mission Management System is an electronic mobile map that allows the creation of a real time tactical picture. The system capabilities represent a revolution in all areas, and are related to combat 
preparation, training, flight preparation, planning and arrangement missions, briefing, teamwork and debriefing.

The MMS - The Mission Management System enables mission planning, field analyzes, and various calculations on the ground, using the field activity station, Mission Preparation Station - MPS, and during the flight using the system in the air. At the same time, the system efficiently integrates the capability of advanced navigation aiming at efficient and accurate mission management, as well as real-time reporting - closed area, threats, etc.

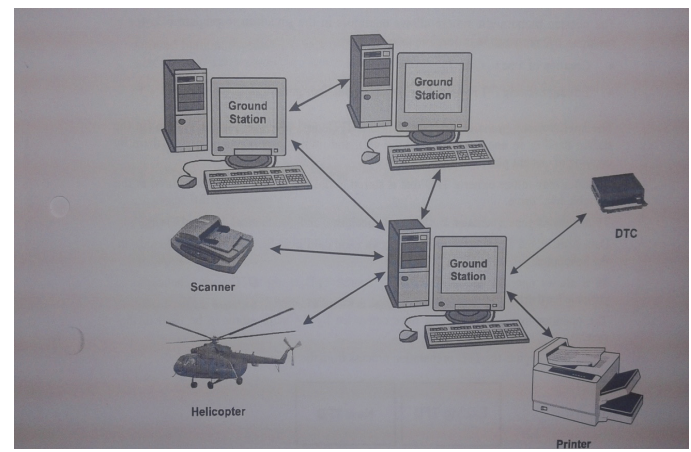

Figure 11 - System block diagram of the MMS

Puc. 11 - Система структурной схемы MMS

Слика 11 - Систем блок-шема на MMS

The Mission Management System allows the pilot and the co-pilot to gather information on the map according to their needs. The map will shows the selected layers from the offered list, for example, a battle sketch, attack/observation of positions and targets, ground forces, etc., thus forming the final sketch of the mission using the layers for each individual map on the site. The MMS is composed of two stations, in the air and on the ground with different functions (Elbit Systems Technical Writing and Customer Training Department, 2006).

The main functions of the air station are: showing the helicopter's position and its direction of movement, shown on the moving map in the cockpit display; modifying and editing existing missions during the flight; operational management of stored data - Way Points - WPs, navigation, navigation programs, graphic displays, attacks and all data and objects of missions; display of the different tactics on the map; various calculations in real time - time management, a line-of-sight, Line of Sight - LOSs, analysis between the helicopter and the selected object, point on the ground or target of attack; the Warning Centre management - which warns on fraudulent actions. 
The main functions of the ground station are: mission planning and preparation; duplication of the new drive for Mission PC - MPC, if needed, video debriefing.

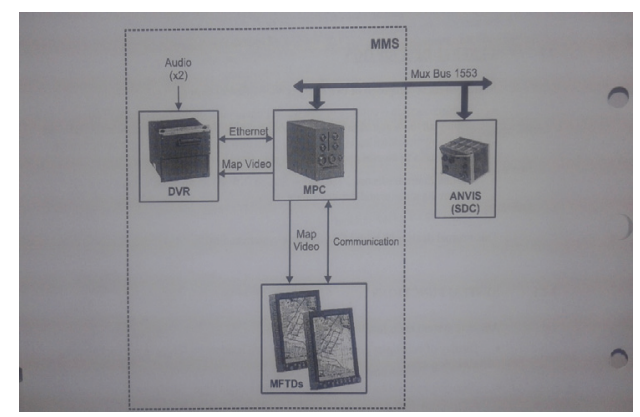

Figure 12 - MMS airborne system - general structure

Puc. 12 - MMS воздушная система - базовая схема

Слика 12 - MMS ваздушни систем - општа шема

The building blocks of the Mission Management System - MMS, are as follows:

MPC - Mission Personal Computer, Mission's PC is the central unit of the MMS system. The MPC performs calculations and controls the MMS units, and works on operational implementation and generates Multi Functional Touch Display-MFTD incoming video. It contains a CPU processor card, a removable HDD hard disk, graphics accelerator, I / O, input / output card and PS or an interactive computer program for performing statistical power. All computer components are fixed and adjusted to the helicopter in flight conditions.

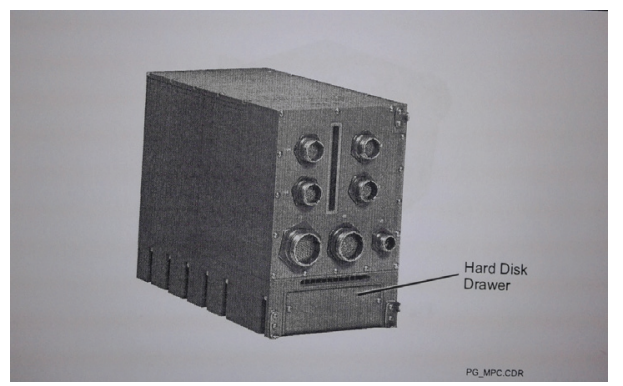

Figure 13 - MPC - Mission Personal Computer Puc. 13-MPC Персональный компьютер для миссии Слика 13 - MPC - Персонални компјутер за мисију

The DVR - Digital Video Recorder, the digital video recorder is a recorder of video and audio data. It enables simultaneous recording of two 
video channels, one or two audio channels on a single cartridge. The DVR allows playback for debriefing intended for the ground station. The DVR records video data in the MPEG-2 format, which saves a lot of disk space without losing video quality. The DVR Digital memory is more immune to the erosion resulting from prolongation of tape lifetime usage. Digital storage provides to the pilot a greater flexibility that is unmatched by analogue tapes.

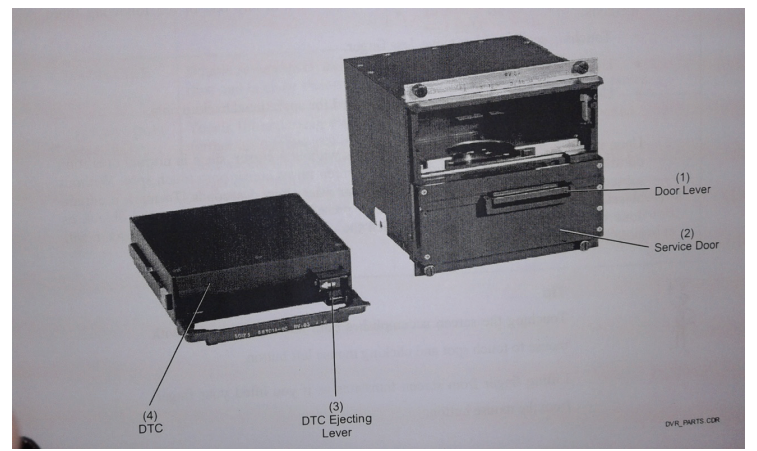

Figure 14 - DVR - Digital Video Recorder

Puc. 14-DVR - Цифровой видеорегистратор

Слика 14 - DVR - Дигитални видео-рикордер

The MFTD - Multi Functional Touch Display, is a multi functional touch screen. The MFTD is a 15.24 by $20.32 \mathrm{~cm}$ colour monitor, mounted on the instrument panel in the cockpit. It serves as a MMI - Man Machine Interface between the MMS and the operators. Using the MFTD, the operators get visual data video from the MPC - Mission Personal Computer and issues the commands to the MMS system - Mission Management system.

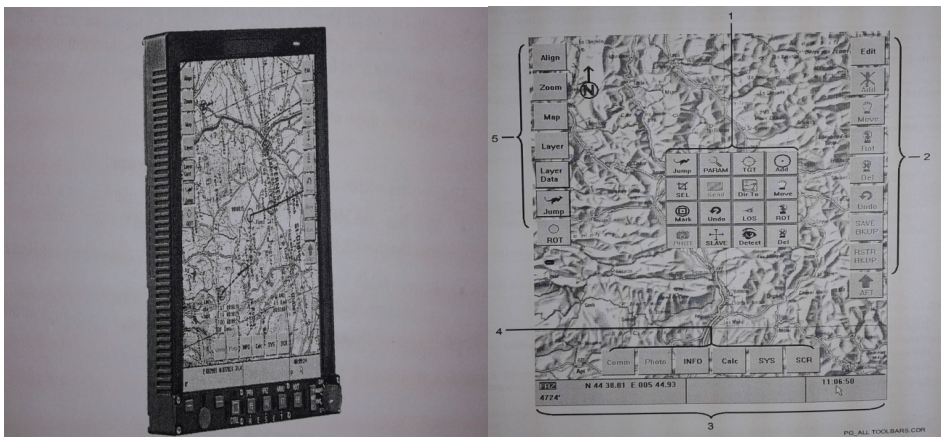

Figure 15 - MFTD - Multi Functional Touch Display Puc. 15 - MFTD - Многоффункциональный сенсорный дисплей Слика 15 - MFTD - Мултифункционални екран на додир 
The MFTD has a touch screen operated by using a finger or a penpointer attached to the screen. A joystick with two buttons can also be used for similar operations. The buttons for fixed-function, which are used to operate the system, are located at the bottom of the screen.

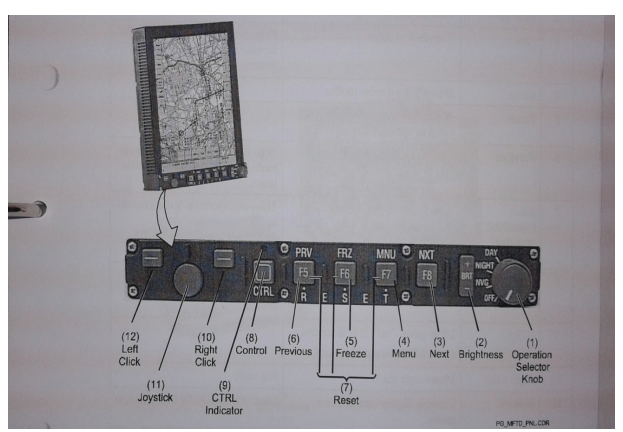

Figure 16 - Fixed-function buttons

Pис. 16 - Кнопки с зависимой фриксацией

Слика 16 - Фиксно-функционална дугмад

The Mi-24V serial 207 from the elite "Night Thunders" squadron departs the range after a live-firing exercise. Macedonia offers plenty of space for low-flying exercises and training with other elements of the armed forces. According to the Commander of the Macedonian Air Force, col. Robert Malezanski, the communications system will be upgraded, and the fuselage, engines and gearboxes will be overhauled. Helicopters are flown to the Aviakon repair plant in Konotop, Ukraine in batches of two. On 10th of June 2016, coinciding with the anniversary of the Aviation Brigade, a contract for the overhaul of four Mi-8/17s and six Mi-24s was signed. The entire process will take two years till end of 2019 (Air Forces, Changing fortunes for Macedonia, 2017).

\section{Conclusion}

Upon laying the foundations of safe and stable flight, designers dedicated their work to increasing efficiency. The Armed Forces have the greatest impact in this field by making new requirements for new missions. They demanded more payload, longer flight lengths and duration of flight, increase of the intervals between maintenance and many other demands.

The fact the Mi-8/17 helicopters operate in extremely difficult conditions is one of their greatest advantages. They are used in many armies and police forces around the world, they are considered safer and 
more modern than most helicopters, and can perform even the most complex operations.

What makes this helicopter special is that it is capable of flying with only one engine in case the second one has a breakdown. That allows the system to distribute the engine power - if the first fails; the strength of the operational one automatically increases to allow for a continued flight.

Mi-8/17 helicopters have been constantly modernized and subjected to alterations, enabling significant improvement of their efficiency. The modernization of the helicopters provides the aviation brigade with increased operational efficiency, especially regarding night flights without the use of lights. The modernization of the assets is a continuous process of any modern military-security structure.

Macedonia's Air Force is developing at a rapid pace, and this is confirmed by the fact that a country aspiring to join NATO has began the modernization of Russian - produced helicopters.

\section{References}

-Air Forces, The world's number one military aviation magazine, 2017. Changing fortunes for Macedonia, August $10^{\text {th }}$. [Internet]. Available at: http://www.airforcesmonthly.com/2017/08/10/changing-fortunes-for-macedonia/. Accessed: 19.09.2017.

-Army of the Republic of Macedonia, 2014. Modernizacija na helikopter Mi8 MT. [Internet]. Available at: http://www.arm.mil.mk/. Accessed: 11.04.2016 (in Macedonian).

-Army technology, 2015. Mi-8/17 Hip Multimission Helicopter-Russia, [Internet]. Available at: http://www.army-technology.com/projects/mi8t/. Accessed: 26.01.2016.

Božić, Ž., 2010. Osnove konstrukcija helikoptera. Zagreb: Fakultet strojarstva i brodogradnje, skripta (in Croatian). Publishers.

Bryan, G.S., 1926. Edison the Man and His Work. New York: Garden City

Dicevski, V., 2012. VV i PVO od pocetokot na svoeto postoenje vo Republika Makedonija do denes. Stit, 36, pp.21-22 (in Macedonian).

Dicevski, V., 2014. Mi-8MT modernizacija na helikopterot. Stit, 59, p.23 (in Macedonian).

Donald, F.L., 1977. Asia in the making of Europe. A Century of Wonder, Volume II.

Edwin, B.W., 2010. Helicopter Man: Igor Sikorsky and His Amazing Invention. New Jersey: City University.

-Elbit Systems Technical Writing and Customer Training Department, 2006. Operational manual Mission Management System (MMS). 
-Flot 2017 Ми-8/Ми-17, 2011. [Internet]. Available at: www.flot2017.com. Accessed: 03.02.2016.

-Focke-Wulf Fw61 / Fa61 Experimental Helicopter / Technology Demonstrator, 2015. The Focke-Achgelis Fw 61 helicopter served Germany well as a technology demonstrator - two were built prior to the war. [Internet]. Available at: http://www.militaryfactory.com. Accessed: 19.10.2015.

Gordon, L.J., 2007. Engineering Analysis of the 1907 Cornu Helicopter. College Park: University of Maryland, Institute of Technology.

Gordon, Y. \& Komissarov, D., 2004. Mil Mi-8 and Mi-17: Rotary-Wing Work Horse and War Horse. Milbank: Midland Publishing.

-Helitage Mi (Mil) Helicopters, 2013. Mil helicopters Mi-17 (8 and 171 E). [Internet]. Available at: www.milhelicopter.com. Accessed: 17.03.2015.

http://kollektsiya.ru. Accessed: 19.10.2015.

https://topwar.ru. Accessed: 17.02.2015.

Kenneth, M., 1968. Aircraft of World War I. Garden City NY: Doubleday and Company.

Kuzmanovski, Z., 2003. Svetot na helikopterite. Skopje (in Macedonian).

Leishman, J.G., 2006. Principles of Helicopter Aerodynamics. Cambridge University Press.

-Ministry of Defence on the Republic of Macedonia, 2012. White book of defence. Skopje: Ministry of Defence on the Republic of Macedonia.

-Museo nazionale scienza e tecnologia Leonardo Da Vinci, 1999. The history of the helicopter from precursors to industrialization. [Internet]. Available at: http://www.museoscienza.org (in Italian). Accessed: 11.08.2015.

-Pioneers-1900/1930, Helicopter History Site. [Internet]. Available at: http://www.helis.com/pioneers/1900.php. Accessed: 26.08.2015.

Rumerman, J., 2003. Early Helicopter Technology. U.S. Centennial of Flight Commission, 2003. [Internet]. Available at: http://www.centennialofflight.net/essay/Rotary/early_helicopters/HE1.htm.

Accessed: 19.10.2015.

-Russian Helicopters, Mi-8/17 Medium Multirole Helicopter, 2015. [Internet]. Available at: http://www.russianhelicopters.aero/en/helicopters/civil/mi-817.html. Accessed: 26.01.2016.

Sikorsky, I., 2013. Aviation Pioneer-Single-Rotor Helicopters. [Internet]. Available at: https://www.asme.org. Accessed: 19.10.2015.

Swanborough, G. \& Bowers, P.M., 1990. United States Navy Aircraft since 1911. Annapolis: Naval Institute Press.

Vlačić, S., 2015. Helikopteri Mi-8/17, letelice bez premca. Odbrana, 243, p.36.

Available at: $h$ ttp://nww.odbrana.mod.gov.rs/svi_clanci_broja.php?id_broja=545\&id_casopisa=1. Accessed: 07.09.2017 godine (in Serbian).

Yona, Z., Weiser, B. \& Hamburger, O., 2004. Day/night ANVIS/HUD-24 (day HUD) flight test and pilot evaluations. SPIE- The International Society for Optical Engineering, Proceedings of the SPIE, 5442, pp.225-235. 
ПОВЫШЕНИЕ ТЕХНИЧЕСКИХ ХАРАКТЕРИСТИК ВЕРТОЛЕТА МИ-8/17 В ПРОЦЕССЕ ВООРУЖЕНИЯ АРМИИ БЮР МАКЕДОНИЯ

Драге Т. Петрески, Андрей П. Илиев, Елена М. Траяновска,

Лазар Б. Джуров, Александар С. Петровски

Военная академия “Генерал Михаило Апостолски”, г.Скопье,

БЮР Македония

ОБЛАСТЬ: аэрокосмическая техника, электроника, телекоммуникации ВИД СТАТЬИ: профессиональная статья

ЯЗЫК СТАТЬИ: английский

Резюме:

Практика в эксплуатации вертолетов МИ-8/17 в целом мире показала, что они являются лидерами между многоцелевыми вертолетами среднего класса высокого эксплуатационного качества с высоким порогом высоты полета при тяжелых метеорологических условиях. В данной работе больщое внимание посвящено изучению развития транспортных, поисковоспасательных и боевых характеристик данных вертолетов. Превосходные технические характеристики в полете и их возможности непрерывного и качественного выполнения задач подтверждают правильность решения об инвестировании в модернизацию этих вертолетов, которое приняли Вооруженные силы БЮР Македонии, а также об инвестировании в повышение их технических характеристик. Модернизация средств в армии всегда является длительным процессом в любой современной структуре военной безопасности. Большинство армий не экономит средств на осуществление целей в усовершенствовании возможностей своей техники, для того чтобы впоследствии оказаться на вершине технологической безопасности и подготовленности своих кадров.

Ключевые слова: модернизация, технические возможности, проект, авиационные средства, эксплуатационные качества, сила.

ПОБОЉШАЊЕ ТЕХНИЧКИХ КАРАКТЕРИСТИКА

ХЕЛИКОПТЕРА МИ-8/17 У НАОРУЖАЊУ

ВОЈСКЕ БЈР МАКЕДОНИЈЕ

Драге Т. Петрески, Андреј П. Илиев, Елена М. Трајановска, Лазар Б. Ђуров, Александар С. Петровски

Војна академија “Генерал Михаило Апостолски”, Скопје, БJP Македонија

ОБЛАСТ: ваздухопловно машинство, електроника, телекомуникације ВРСТА ЧЛАНКА: стручни чланак

ЈЕЗИК ЧЛАНКА: енгЛескИ 


\section{Сажетак:}

Искуства из целог света су показала да су хеликоптери МИ-8/17 на врху листе вишенаменских хеликоптера средње класе са високим перорормансама за високо летење у сложеним временским и метеоролошким условима. Циљ овог рада је да се проучи њихов развој, као и транспортне, спасилачке и борбене могућности ових летелица. Одличне техничке карактеристике за летење и њихове способности за неометано и квалитетно извршавање намењених задатака показују зашто је Војска БJP Македоније одлучила да улаже у модернизацију ових хеликоптера и усавршавање њихових техничких способности. Модернизација средстава у једној армији је континуиран процес у свакој савременој војнобезбедносној структури. Велики број армија не итеди средства намењена за ове циљеве, како би оствариле оспособљеност снага и обученост људства у складу са технологијом.

Кључне речи: модернизација, техничке могућности, пројекат, ваздухопловна средства, перформансе, сила.

Paper received on / Дата получения работы / Датум пријема чланка: 12.07.2017. Manuscript corrections submitted on / Дата получения исправленной версии работы / Датум достављања исправки рукописа: 10.11.2017.

Paper accepted for publishing on / Дата окончательного согласования работы / Датум коначног прихватања чланка за објављивање: 13.11.2017.

(c) 2018 The Authors. Published by Vojnotehnički glasnik / Military Technical Courier (www.vtg.mod.gov.rs, втг.мо.упр.срб). This article is an open access article distributed under the terms and conditions of the Creative Commons Attribution license (http://creativecommons.org/licenses/by/3.0/rs/).

() 2018 Авторы. Опубликовано в «Военно-технический вестник / Vojnotehnički glasnik / Military Technical Courier» (www.vtg.mod.gov.rs, втг.мо.упр.срб). Данная статья в открытом доступе и распространяется в соответствии с лицензией «Creative Commons» (http://creativecommons.org/licenses/by/3.0/rs/).

(C) 2018 Аутори. Објавио Војнотехнички гласник / Vojnotehnički glasnik / Military Technical Courier (www.vtg.mod.gov.rs, втг.мо.упр.срб). Ово је чланак отвореног приступа и дистрибуира се у складу са Creative Commons licencom (http://creativecommons.org/licenses/by/3.0/rs/).

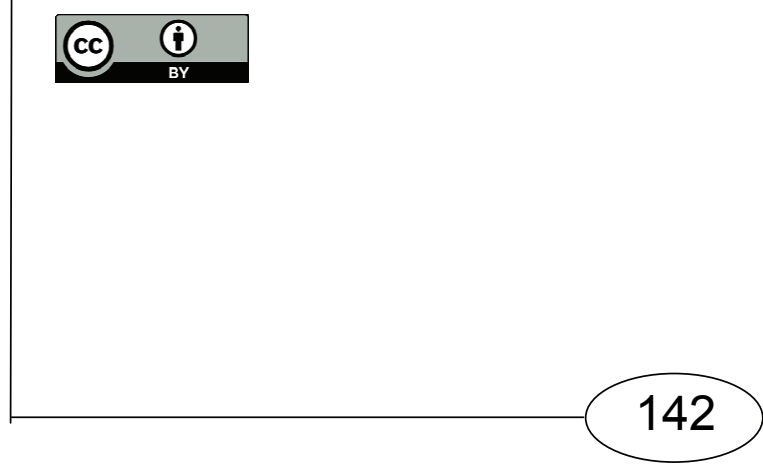

